\title{
FORMATION OF LEVEL AGENDA PROGRAMS COMPETENCY OF THE PERSONNEL OF THE ORGANIZATION
}

\author{
S.A. Barkalov', sbarkalov@nm.ru, \\ V.N.Burkov², vlab17@bk.ru, \\ N.Yu.Kalinina1, kalinina@vgasu.vrn.ru, \\ T.V. Nasonova', tnasonova@vgasu.vrn.ru \\ ${ }^{1}$ Voronezh State Technical University, Voronezh, Russian Federation, \\ ${ }^{2}$ V.A. Trapeznikov Institute of Control Sciences of Russian Academy of Sciences, \\ Moscow, Russian Federation
}

\begin{abstract}
At present, when the requirements to the quality of education are significantly increased, there is a need to search for new methods to increase the competence of the teaching staff of educational institutions.

Competences that include a body of knowledge, skills, abilities, applied efforts and behavior stereotypes are characteristics that are necessary for a person to succeed, and competence means the person's own competence. Competence is a versatile, diverse and systemic characteristic of the teacher.

The current multidimensional approach to competence offers more opportunities for integrating business requirements, human resource management technologies and the educational process. In this regard, it is important to develop a model support for the process of assessing and improving the level of competence of teaching staff.

The article considers the task of increasing the level of competence of the personnel of the organization. The approach is based on the technology of developing development management systems (DMS technology), created in the Institute of Control Sciences of the Russian Academy of Sciences. The main stages of the DMS technology are considered as applied to the task of increasing the level of competence of the organization, such as a comprehensive assessment of the level of competence of the organization, assessing the potential for increasing the level of competence of personnel, developing a program to improve the level of competence.

Keywords: competence, integrated assessment, development management, program, convolution matrix, branch and boundary method, network programming method.
\end{abstract}

At the present time, the requirements to the quality of education on the part of the state, applicants and employers are significantly increased, the competition among universities is becoming more acute, and the economic conditions of the universities are changing. All this raises the problem of finding new sources of increasing the competitiveness of a higher educational institution (HEI). In the documents of international organizations, domestic legislative and regulatory acts on higher education, it is noted that the most important condition for improving the quality of higher education is the competence of the teaching staff. Competences are stable characteristics of the human personality, predetermining the behavior of a person in a variety of situations and work tasks [1]. Modern research shows that recruitment through the competence model leads to an increase in staff efficiency, compared to other selection methods.

At present, a multidimensional (holistic) approach to competence is becoming widespread [2], which offers more opportunities for integrating business requirements, human resource management technologies and the educational process. The competence model is the basis for the adoption of any personnel decisions and procedures such as hiring, attestation, office travel, skills development, motivation and payment systems.

The current state of the problem does not allow to simulate the optimal trajectory of increasing the competence of personnel within the existing limitations for a particular organization [3]. In this regard, it is important to develop a model support for the assessment process and increase the level of competence of the faculty of the university. 
The article considers the task of increasing the level of competence of the personnel of the organization. The approach is based on the technology of developing development management systems (RMS technology), created in the Institute of Control Sciences of the Russian Academy of Sciences with the participation of leading consultants in strategic management. The main stages of the RMS technology are considered as applied to the task of increasing the level of competence of the organization, such as a comprehensive assessment of the level of competence of the organization, assessing the potential for increasing the level of competence of personnel, developing a program to increase the level of competence, building a program implementation schedule.

Consider a comprehensive assessment of the level of competence of an organization from several departments. For definiteness, let it be an institution consisting of $x$ departments (Fig. 1).

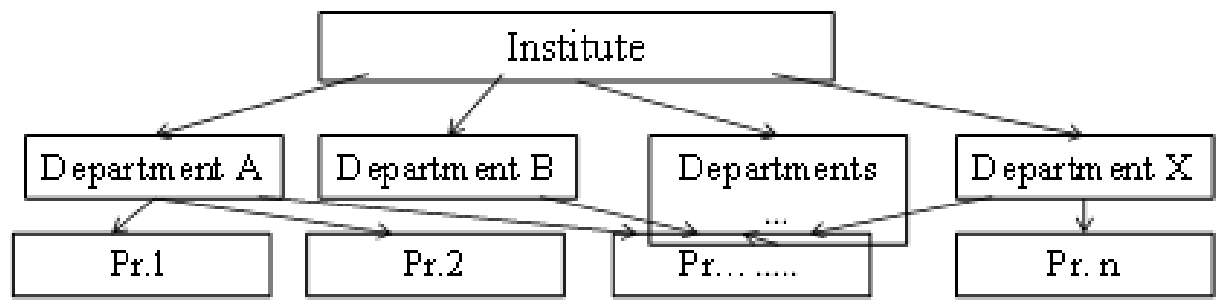

Fig. 1. The organizational structure of the institute

Each employee (teacher) of the institute has a certain level of competence. To assess this level, formal indicators (summaries, academic degrees, length of service, etc.), subjective (expert) assessments, including interviews and interviews, results of attestation are used. Assume that the level of competence is assessed on a three-point scale: normal level -1 , elevated -2 , high -3 .

The level of competence of the Institute's personnel will be assessed as follows. Let $n$ - number of the higher teaching staff; $n_{1}$ - number of the higher teaching staff having a normal level of competence; $n_{2}$ - the number of the higher teaching staff having an elevated level of competence; $n_{3}$ - the number of the higher teaching staff having a high level of competence. We denote by $Y=n_{1}+2 n_{2}+3 n_{3}$ the sum of the levels of competence of the institute's the higher teaching staff. We introduce the boundary values: $A_{0}=q_{0} n, A_{1}=q_{1} n, A_{2}=q_{2} n$, где $q_{1}<q_{2}<1$.

If $Y<A_{0}$, this is a low level of competence and organizational measures are required.

If $A_{0} \leq Y<A_{1}$, then the institute has a normal level of competence of the higher teaching staff.

If $A_{1} \leq Y<A_{2}$, then the institute has an increased level of competence.

If $Y \geq A_{2}$, then the institute has a high level of competence.

To assess the level of competence of PPP as a whole, the matrix convolution apparatus is applicable. We define the dichotomous structure (binary tree) of the pairwise aggregation of the competence levels of the institutions' higher teaching staff. In Fig. 2 shows an example of such a structure for the case of the four institutions.

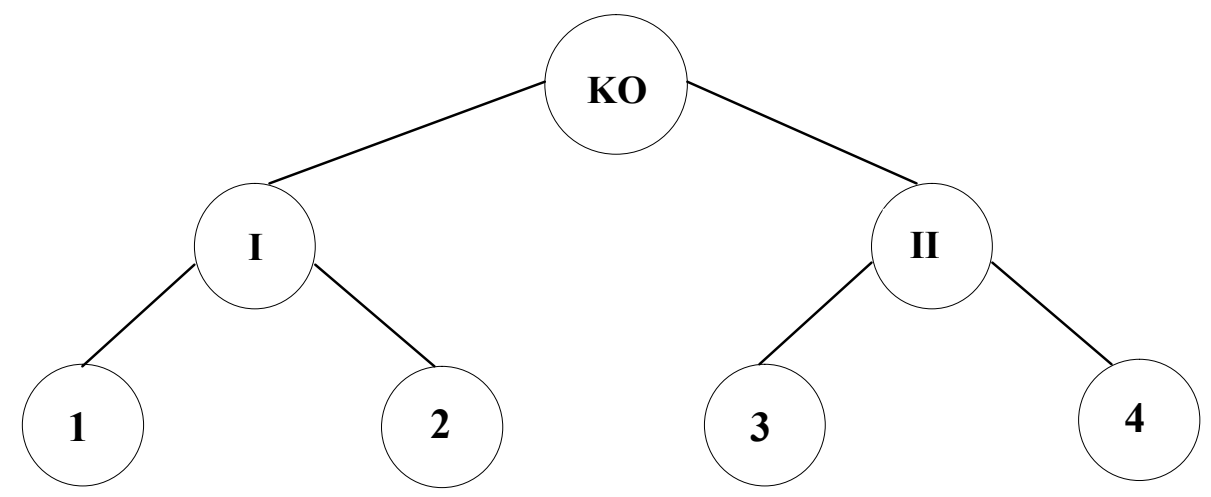

Fig. 2. Example of a dichotomous structure (binary tree) 


\section{Управление в социально-экономических системах}

First, an integral assessment of the level of competence of institutes 1 and 2, as well as 3 and 4 is determined. Then a comprehensive assessment of the level of competence of the combined institutes

\begin{tabular}{|c||c|c|c|}
\hline 3 & 2 & 3 & 3 \\
\hline 2 & 1 & 2 & 3 \\
\hline 1 & 1 & 2 & 2 \\
\hline \hline 2 & 1 & 2 & 3 \\
\hline
\end{tabular}

I and II is determined. It is desirable to unite close (in terms of direction, in the number of students or in the institutions' number of the higher teaching staff.

The definition of aggregated estimates is based on $3 \times 3$ matrices. An example of such an aggregation matrix for estimating institutions 1 and 2 is shown in Fig. 3.

The choice of matrices is determined by the university's policy (priorities of institutions). Thus, from the matrix in Fig. 3 that the institute 1 has a certain priority before the institute 2 . Indeed, in the evaluation of the second institute and the second one, the integral estimate is 2 , and in the reverse picture (the score of

Fig. 3. Example of the aggregation matrix of structural unit estimates 1 from the first institution and the estimate of 2 from the second) the integral estimate is 1 . Having method of assessing the level of competence of the institution as a whole, it is possible to solve the problem of increasing this assessment.

The assessment of the potential for increasing the level of staff competence (the higher teaching staff) is based on the integration of many activities aimed at improving the level of competence - internships, participation in conferences, invitations to leading scientists, writing textbooks and monographs, preparing dissertations, developing incentive mechanisms for raising the level of competence, etc. Each the event will be evaluated by two characteristics - the cost of the event and the effect of the event (that is, an increase in the indicator of the competence level of the unit).

We denote by $c_{i}$ - expenses, $a_{i}$ - effect $i$-th's event, $Y_{0}$ - existing level of competence; $\Delta$ - the amount by which the level of competence needs to be increased; $s_{i j}$ - minimum costs required for the transition $i$-th of structural subdivision in group $j$.

Ratio

$$
q_{i}=\frac{a_{i}}{c_{i}}
$$

determines the effect of $i$-th's event.

We number the measures in order of decreasing efficiency. Then, based on these data, you can solve two problems. If you want to increase the level of competence by the required amount, then using this data you can determine what minimum amount is required for this. Conversely, if there is a certain amount allocated to increase the level of competence, then based on the same data, you can determine what the maximum increase in the level of competence can be obtained.

If $Y_{0}<A_{1}$, то разность $\Delta_{1}=A_{1}-Y_{0}$ determines the minimum increase in the level of competence required to transition to the group of enhanced competence; a $\Delta_{2}=A_{2}-Y_{0}$ - determines the minimum increase in the level of competence required to transition to a group of high-level competencies.

Consider the task of forming a program to increase the level of competence. Without loss of generality, we assume that the existing level of competence is equal to one and the minimum cost matrix is defined.

A variant of raising the level of competence is the aggregate $x=\left(x_{i}\right)$ of assessments of the level of competence of institutions to which a comprehensive assessment corresponds $\pi(x)$. Then the task is set: to determine the $x$, providing the required value of the integrated assessment $\pi(x)$ with minimal costs. The algorithm for solving the problem is based on the method of dichotomous programming [1]. In fact, there may exist so-called multi-purpose measures, the implementation of which gives effect at once for several institutions. Such events include, for example, the organization of conferences, the invitation of leading scientists with lectures, etc. Let us consider two approaches to solving the problem in the presence of multi-purpose measures.

1 approach. If the number of multipurpose activities is not large, then it is possible to consider all options for entering the program of multi-purpose activities (such options $2^{q}$, where $q$ - the number of multi-purpose events). With a fixed variant of entering into the program of multi-purpose measures, we obtain the problem considered above with single-purpose measures. Of all the options, then the best one 
is chosen. With a large number of multipurpose activities, the method of enumerating all the variants of their entry into the program becomes time-consuming.

2 approach. We apply the branch and bound method to obtain lower bounds based on the network programming method by I.V. Burkova [4]. To do this, we divide the costs of each multipurpose event arbitrarily into several parts according to the number of institutions in which this exercise gives effect. After this, we get the task with single-purpose measures. The task of determining the division of costs for multi-purpose activities, in which the lower estimate of costs is maximum, is called a generalized dual problem.

The obtained estimate is used in the method of branches and boundaries. However, after each branch, you can try to improve the estimate by adjusting the breakdown of costs. In some cases, this method reduces the number of branches. For this purpose the theorem on obtaining lower bounds is used: "The solution of the problem with single-purpose measures gives an estimate from below for the original problem".

The "cost-effect" method provides an approximate solution to the problem of including an event in a program. With a large number of events, the error is not significant. However, with a small number of measures, the error can be significant [5]. In this case, it is expedient to apply the exact algorithm of dichotomous programming.

Another factor that should be taken into account is associated with so-called interdependent activities. When you include a pair of interdependent activities, an additional (synergistic) effect arises in the program (the effect of a couple of activities exceeds the sum of the effects of these activities). This circumstance can be taken into account by constructing a graph of interdependencies.

Definition of the graph of interdependencies: The vertices of the graph correspond to the activities, two vertices $i, j$ are connected by an edge if the corresponding measures are interdependent. The length of an edge is equal to the additional effect $d_{i j}$.

First, we consider a particular case of a problem where the graph interdependent can be a matching (a graph whose no two edges have a common vertex). In this case, the problem is effectively solved by the method of dichotomous programming (for integer values of the parameters). In Fig. 4 shows an example of a graph of interdependencies of five vertices, which is matching.

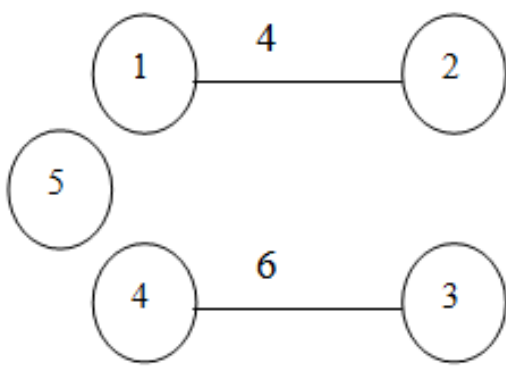

Fig. 4. Example of graph of interdependencies

To solve the problem, we take the structure of the dichotomous representation of the problem, such that the vertices connected by an edge are considered at the lower levels of the dichotomous representation tree (Fig. 5).

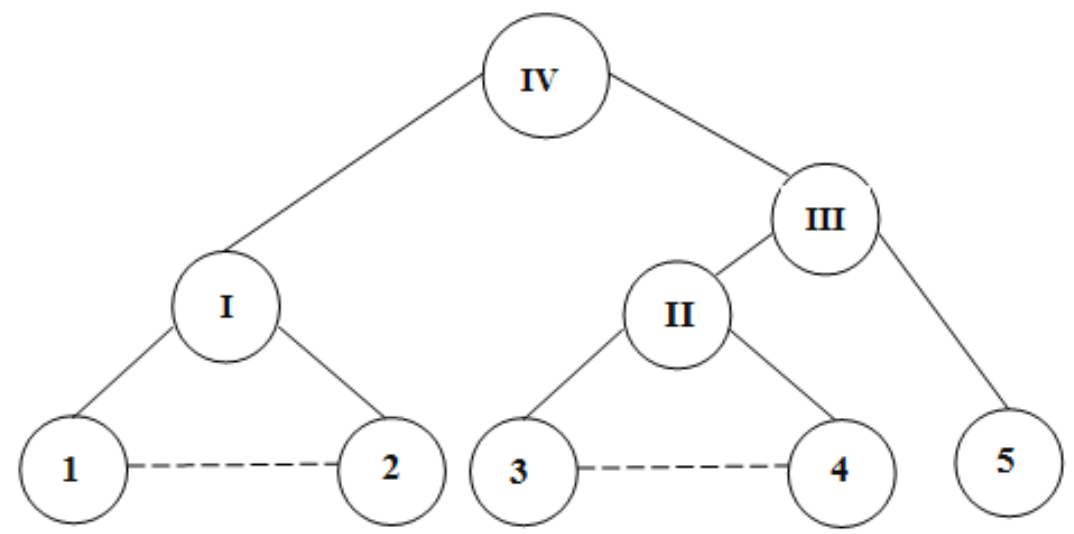

Fig. 5. The structure of the dichotomic representation of the problem

Let us consider the general case. A subgraph is called a subgraph of a graph, which is matching. A paragraph with the maximum number of vertices is called the maximal paragraph.

The idea of the algorithm is as follows. Remove a number of vertices from the graph of interdependencies so as to obtain a paragraph. Further, as in the case of multi-purpose events, we consider all 


\section{Управление в социально-экономических системах}

options for including remote vertices in the program. For each variant we solve the problem for the case of a paragraph. Of all the options we choose the best.

Naturally, it is desirable to obtain a paragraph with the maximum number of vertices, that is, the maximum paragraph. We denote by $x_{i}=1$, if the vertex $i$ belongs to the maximal paragraph, $x_{i}=0$ otherwise. The task is to maximize $\sum_{i} x_{i}$ under constraints $x_{i} \sum_{j \in Q_{i}} x_{j} \leq 1, i=\overline{1, n}$, where $Q_{i}$ - set of vertices adjacent to the vertex $i$. The task is a complex task of discrete optimization, which does not have effective exact methods of solution.

Let's describe a simple heuristic algorithm.

1 step. For each edge of the graph we define the number of vertices $r_{i j}$, adjacent to the boundary vertices of the edge.

2 step. Define an edge $(i, j)$ with minimal $r_{i j}$ and include it in the paragraph.

3 step. Delete all vertices adjacent to the edge $(i, j)$, and repeat steps $1,2,3$.

Example. There are six activities, the data of which are given in Table 1.

Table 1

Facts cost-effectiveness measures

for improving competencies

\begin{tabular}{|l|c|c|c|c|c|c|}
\hline$i$ & 1 & 2 & 3 & 4 & 5 & 6 \\
\hline$a_{i}$ & 5 & 7 & 9 & 8 & 12 & 4 \\
\hline$c_{i}$ & 8 & 7 & 6 & 4 & 3 & 2 \\
\hline
\end{tabular}

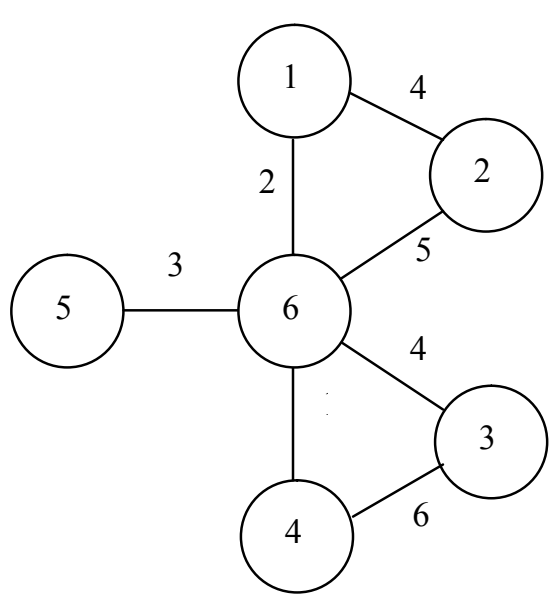

Fig. 6

Consider the graph (Fig. 6).

It is easy to verify that the edges $(1,2)$ and $(3,4)$ have minimal $r_{12}=r_{34}=1$.

We include, for example, an edge $(1,2)$ in a paragraph, removing the vertex 6 .

We obtain the part (see Fig. 4). Since one vertex is removed, it is necessary to consider two variants (see Table 1).

1 option. Activity 6 is not included in the program. In this case, the minimum costs are 13 .

2 option. Activity 6 is included in the program. Values $d_{i 6}, i=\overline{1,5}$, are shown in Fig. 6 . Add additional effects to the effects of vertices $d_{i 6}, i=\overline{1,5}$.

Correct the target setting $\Delta=30-a_{6}=26$.

1 step. We consider measures 1 and 2 . We are considering the combined event II and activity 5 (Table 2 ).

The results are tabulated (Table 3).

Table 2

Table 3

\begin{tabular}{|c|c|c|c|}
\hline \multicolumn{2}{|c|}{1} & $12 ; 7$ & $19 ; 15$ \\
\hline \multicolumn{2}{|c|}{0} & 0 & $7 ; 8$ \\
\hline 2 & & 0 & 1 \\
\hline
\end{tabular}

Joint Event I

\begin{tabular}{|l|c|c|c|}
\hline Variant & 0 & 1 & 2 \\
\hline Effect & 0 & 12 & 19 \\
\hline Costs & 0 & 7 & 15 \\
\hline
\end{tabular}

2 step. We consider activities 3 and 4. The solution is given below (Table 4).

The results are tabulated (Table 5). 
Table 4

\begin{tabular}{|c|c|c|}
\hline 1 & $9 ; 4$ & $22 ; 10$ \\
\hline 0 & 0 & $13 ; 6$ \\
\hline & 0 & 1 \\
\hline
\end{tabular}

Table 5

Joint Event II

\begin{tabular}{|l|c|c|c|c|}
\hline Variant & 0 & 1 & 2 & 3 \\
\hline Effect & 0 & 9 & 13 & 22 \\
\hline Costs & 0 & 4 & 6 & 10 \\
\hline
\end{tabular}

3 step. We are considering the combined event II and activity 5.

We are considering the combined event II and activity 5 (Table 6).

Table 6

Joint Event III

\begin{tabular}{|c|c|c|c|c|}
\hline 1 & $15 ; 3$ & $24 ; 7$ & $28 ; 9$ & $37 ; 13$ \\
\hline 0 & 0 & $9 ; 4$ & $13 ; 6$ & $22 ; 10$ \\
\hline 5 & 0 & 1 & 2 & 3 \\
\hline
\end{tabular}

4 step. We consider the combined activities I and III. The solution is given below (Table 7).

Table 7

\begin{tabular}{|c|c|c|c|c|c|}
\hline 2 & $19 ; 15$ & $34 ; 18$ & - & - & - \\
\hline 1 & $12 ; 7$ & $27 ; 10$ & $36 ; 14$ & - & - \\
\hline 0 & 0 & $15 ; 3$ & $24 ; 7$ & $28 ; 9$ & $37 ; 13$ \\
\hline III & 0 & 1 & 2 & 3 & 4 \\
\hline
\end{tabular}

The optimal solution is determined by the cell $(37 ; 13)$ with costs $13+2=15$. We choose the first option.

The final stage in the formation of the program is the construction of a calendar plan for its implementation. Let the integral program financing schedule be given. The task is to determine the timing of each event, so that the required funding of activities at any given time does not exceed the funds allocated to this time. As a criterion of optimality, we take the value of the lost profit.

First you need to check the financial feasibility of the program. To do this, we construct a rightadvanced implementation plan (all activities are completed at a given point in time) and an integral schedule for its financing.

Terms of financial realizability of the program: an integral right-shifted financing schedule should not be higher than the integral schedule for financing the program at any one time.

The task is a complex optimization problem that does not have effective, accurate methods of solution. Therefore, we propose a heuristic algorithm, based on the priority rules of measures.

To justify the proposed priority rules for events, we consider two particular situations.

1 situation. The integrated financing schedule is such that the activities can only be carried out sequentially. We get the well-known task of determining the sequence of performance of measures, minimizing lost profits. It is proved that in this case it is optimal to carry out activities in the order of decreasing priorities:

$$
\tau_{i}=\frac{a_{i}}{\tau_{i}}
$$

where $\tau_{i}$-duration of the event $i$. 


\section{Управление в социально-экономических системах}

2 situation. Financing is carried out for periods, and each activity can be fully executed in one period ( $\tau_{i} \leq \theta$, where $\theta$ - duration of one period). In this case, a solution close to optimal is obtained on the basis of the "cost-effect" method, that is, the implementation of activities in the order of priorities:

$q_{i}=\frac{a_{i}}{c_{i}}, i=\overline{1, n}$.

So, we have two priority rules for events. A heuristic algorithm was proposed in [6], in which a linear combination of these rules is proposed:

$p_{i}(\lambda)=\lambda r_{i}+(1-\lambda) q_{i}$

where $0 \leq \lambda \leq 1$.

Value $\alpha$ is chosen arbitrarily, which can lead to the loss of a number of options. We propose to consider all variants of priorities (their number does not exceed $1+c_{n}^{2} ; c_{n}^{2}$ - number of combinations from $n$ to 2 ). tion

To determine these priorities for each pair of measures, we define the boundary value $i$ from equa-

$\alpha r_{i}+(1-\alpha) q_{i}=\alpha r_{j}+(1-\alpha) q_{j}$.

We get (if $q_{i}>q_{j}$ ):

$\alpha_{i j}=\frac{q_{i}-q_{j}}{\left(r_{j}-r_{i}\right)+\left(q_{i}-q_{j}\right)}$.

If $q_{i}=q_{j}$, priority is greater for an event with a larger $r$, regardless of size $\alpha$. The transition of $\alpha$ boundary points $\alpha_{i j}$ leads to a change of priorities.

\section{References}

1. Barkalov S.A., Davidova T.E., Kalinina N.Yu., Kurnosov V.B. Kompetentnostnyy podkhod v upravlenii personalom: otsenka, obucheniye, komandoobrazovaniye [Competence Approach in Personnel Management: Assessment, Training, Teambuilding]. Voronezh, Nauchnaya kniga Publ., 2010. $184 \mathrm{p}$.

2. Barkalov S.A., Moiseev S.I., Kocherga N.S., Solov'yeva E.V. [Mathematical Models of Training and Quality Assurance of Mastering Competences in the Educational Process]. Open Education, 2014, no. 2, pp. 9-16. (in Russ.)

3. Barkalov S.A., Kalinina N.Yu., Nasonova T.V. [The Tasks of Increasing the Level of Competence of the Organization's Staff]. Economics and Management Systems Management, 2017, no. 3.1 (25), pp. 110-116. (in Russ.)

4. Burkova I.V. [The Method of Network Programming in Problems of Nonlinear Optimization]. Automation and Telemechanics, 2009, no. 10, pp. 15-21. (in Russ.)

5. Barkalov S.A., Belousov V.E., Sanina N.V. Kvalimetriya [Qualimetry]. Voronezh, Nauchnaya kniga Publ., 2013. 394 p.

6. Burkov V.H., Zalozhnev A.Yu., Novikov D.A. Teoriya grafov v upravlenii organizatsionnymi sistemami [Theory of Graphs in the Management of Organizational Systems]. Moscow, SINTEG Publ., 2001. $265 \mathrm{p}$.

Received 6 February 2018 


\title{
ФОРМИРОВАНИЕ ПРОГРАММ ПОВЫШЕНИЯ УРОВНЯ КОМПЕТЕНТНОСТИ ПЕРСОНАЛА ОРГАНИЗАЦИИ
}

\author{
С.А. Баркалов ${ }^{1}$, В.Н. Бурков ${ }^{2}$, Н.Ю. Калинина', Т.В. Насонова' \\ ${ }^{1}$ Воронежский государственный технический университет, г. Воронеж, Россия, \\ ${ }^{2}$ Институт проблем управления им. В.А. Трапезникова РАН, г. Москва, Россия
}

\begin{abstract}
В настоящее время, когда существенно повышаются требования к качеству образования, возникает необходимость поиска новых методов повышения компетентности преподавательского состава учебных заведений.

Компетенции, включающие совокупность знаний, навыков, способностей, прилагаемых усилий и стереотипов поведения, являются характеристиками, которые необходимы человеку для успешной деятельности, а компетентность означает владение человеком соответствующими компетенциями. Компетентность является многосторонней, разноплановой и системной характеристикой преподавателя.

Распространенный в настоящее время многомерный подход к компетентности предлагает более широкие возможности для интеграции требований бизнеса, технологий по управлению персоналом и образовательного процесса. В этой связи актуальной является разработка модельного обеспечения процесса оценки и повышения уровня компетентности преподавательского персонала.

В статье рассматривается задача повышения уровня компетентности персонала организации. В основе подхода лежит технология разработки систем управления развитием (технология СУР), созданная в Институте проблем управления РАН. Рассматриваются основные этапы технологии СУР применительно к задаче повышения уровня компетентности организации, такие как комплексная оценка уровня компетентности организации, оценка потенциала роста уровня компетентности персонала, формирование программы повышения уровня компетентности, построение календарного плана реализации программы.
\end{abstract}

Ключевые слова: компетентность, комплексная оценка, управление развитием, программа, матрица свертки, метод ветвей и грании, метода сетевого программирования.

\section{Лuтература}

1. Компетентностный подход в управлении персоналом: оценка, обучение, командообразование / С.А. Баркалов, Т.Е. Давыдова, Н.Ю. Калинина, В.Б. Курносов. - Воронеж: Научная книга, 2010. $-184 c$.

2. Математические модели подготовки и проверки качества освоения компетенщий в образовательном прочессе / С.А. Баркалов, С.И. Моисеев, Н.С. Кочерга, Е.В. Соловьева // Открытое образование. - 2014. - № 2. - С. 9-16.

3. Насонова, Т.В. Задачи повышения уровня компетентности персонала организации / С.А. Баркалов, Н.Ю. Калинина, Т.В. Насонова // Экономика и менеджмент систем управления. 2017. - № 3.1 (25). - C. 110-116.

4. Буркова, И.В. Метод сетевого программирования в задачах нелинейной оптимизации / И.В. Буркова // Автоматика и телемеханика. - 2009. - № 10. - С. 15-21.

5. Баркалов, С.А. Квалиметрия / С.А. Баркалов, В.Е. Белоусов, Н.В. Санина. - Воронеж: Научная книга, 2013. - 394 с.

6. Бурков, В.Н. Теория графов в управлении организационными системами / В.Н. Бурков, А.Ю. Заложнев, Д.А. Новиков. - М.: СИНТЕГ, 2001. -265 с. 


\section{Управление в социально-экономических системах}

Баркалов Сергей Алексеевич, д-р техн. наук, заведующий кафедрой управления строительством, Воронежский государственный технический университет, г. Воронеж; sbarkalov@nm.ru.

Бурков Владимир Николаевич, д-р техн. наук, профессор, главный научный сотрудник, Институт проблем управления им. В.А. Трапезникова РАН, г. Москва; vlab17@bk.ru.

Калинина Наталия Юрьевна, канд. техн. наук, доцент кафедры управления строительством, Воронежский государственный технический университет, г. Воронеж; kalinina@vgasu.vrn.ru.

Насонова Татьяна Владимировна, проректор по организационно-правовой работе, Воронежский государственный технический университет, г. Воронеж; tnasonova@vgasu.vrn.ru.

Поступила в редакцию 6 февраля 2018 г.

\section{ОБРАЗЕЦ ЦИТИРОВАНИЯ}

Formation of Level Agenda Programs Competency of the Personnel of the Organization / S.A. Barkalov, V.N. Burkov, N.Yu. Kalinina, T.V. Nasonova // Вестник ЮУрГУ. Серия «Компьютерные технологии, управление, радиоэлектроника». - 2018. - Т. 18, № 2. C. $112-120$. DOI: $10.14529 /$ ctcr180211

\section{FOR CITATION}

Barkalov S.A., Burkov V.N., Kalinina N.Yu., Nasonova T.V. Formation of Level Agenda Programs Competency of the Personnel of the Organization. Bulletin of the South Ural State University. Ser. Computer Technologies, Automatic Control, Radio Electronics, 2018, vol. 18, no. 2, pp. 112-120. DOI: $10.14529 /$ ctcr180211 